\title{
THE DEFIANT ONES: A COMMON FORM OF CHARACTER PATHOLOGY IN CHILDREN
}

\author{
Morton Chethik
}

\begin{abstract}
The paper focuses on a common kind of childhood psychopathology that is often misdiagnosed as incorrigibly delinquent and psychopathic. Many children with a chronic history of defiance and antisocial behavior are struggling with intense internal conflicts. The etiology and dynamics of these youngsters, as well as the treatment implications and techniques, are discussed.
\end{abstract}

\section{INTRODUCTION}

One of the most common referrals to psychiatric clinics for children is the fighting, defiant, and "out of control" youngster who is very actionoriented. This young patient exhibits trouble at home with discipline, problems with peers through provocation, and characteristically many create behavior issues in school. Throughout his history, his early years, this action discharge mode is often in evidence. As a study group at the University of Michigan, we have delineated a significant percentage of these children as potential character disorders - they are "on their way" to consolidating a permanent antisocial character pattern in adolescence or young adulthood. While this may be their fate, we will be discussing a particular group of character pathology that is not psychopathic.

In attempting to understand this group of children, Freud's discussion in "Analysis Terminable and Interminable" (1937) seems particularly relevant. He describes a group of adult patients for whom "quantitative factors" in their personality makes treatment very difficult; they struggle with the excessive strength of their instincts due to constitutional factors or developmental experiences and find it much harder at every stage of development to "tame these instincts." He further discuses two major implications for development due to this struggle. First, they characteristically have a low threshold for frustration of instinctual wishes, and thereby tend toward immediate discharge of tension. Second, they have a low threshold for the tolerance of anxiety. The difficulties in anxiety lead to an excessive use of defensive activity and symptom formation. 
Our youngsters generally show marked problems in the delay of discharge of instinctual drives, as well as massive defensive structures. Particularly prominent is the mechanism of "identification with the aggressor," and this defensive pattern fits these children, since it has an important discharge mode. In the developmental histories of our youngsters, they have much difficulty in superego formation. They appear at first to be able to internalize the parental prohibitions. But because of the threat of punishment and the particular anxiety it stirs, they quickly identify themselves with the threatening figure to avoid imagined projected danger. This pattern quickly becomes a vigorous and pervasive defensive mode that seems to permeate the whole personality.

The purpose of this paper is to highlight some of the typical treatment problems and techniques we have developed with the massive resistances these children employ. Our interventions are often major repeated defensive interpretations. Fortunately, many of these children have not fully developed the "armor plating of the personality" that comes with time. Their defenses are not as solidified as the adult's, and anxiety as an affect still remains therapeutically available. Some of these techniques will be discussed through the presentation of Roger L., a handsome, energetic, and defiant late-latency-aged youngster.

\section{Case Example}

Picture, History, and Early Diagnostic Comments. One was immediately impressed with Roger's precocious "macho" quality and his premature manliness. He had a swagger, a tough gait, and cursed easily and fluently in his initial meetings with his therapist, though he was only 10 years old. Roger was the middle child in a sibship of three; a sister two years older, and a brother two years younger. He came from a middle-class, educated, professional family. The parents were concerned about their son's intense rages. For example, Roger reacted with fury to his father's demands: "Turn down the radio" would provoke a loud blasting of rock and roll music; "Close the car window" would be met wwith an increase in the flow of air. Roger was often in trouble in school. He fought constantly, often losing out to older children, but always taking on a "dare." His fighting led to detentions and a series of suspensions from school. He could provoke his teacher by greeting her with " $\mathrm{Hi}$, stupid" as he entered the classroom in the morning.

At age 10, the parents were already worried about his major attraction to the Lepke gang in the neighborhood, a group of young tough adolescents who were noted for their interest in drugs and minor vandalism. Generally, the parents were strong effective people, but with Roger, father was often provoked into counterage (yelling, screaming) and mother developed a placating accommodating role to avoid trouble.

In the history, Roger was remembered as a very active baby, enjoyed by the family. As an energetic toddler, mother found him hard to pursue at times, but though Roger was vigorous, he seemed happy and alert. He was, however, very frightened in the process of toilet training, especially avoiding the potty, and it 
took him six months to accomplish this task at two-and-a-half years. Mother felt she put little pressure on Roger, and was surprised by his struggle. Both parents felt it was striking that he became very frightened and somewhat alienated from his father at that time, particularly afraid of his father's deep, loud, booming voice and his mustache. However, by about three-and-a-half, the pattern of defiance that was described above began, and generally spread. Roger now did not fear his father; he defied him. He fought the daily demands with a characteristic "No, I won't. You can't make me." Accompanying Roger's counterphobic stance during the years were shortened periods of symptom formation. Sleep problems, enuresis, and tics were evident, periodically lasting at times for several months.

In the initial meetings with Roger, he knew he was coming to see a therapist because of his "bad temper." He described how he was beset, however, by hosts of classmates who provoked him, and one could only expect that he would defend himself. Similarly, his brother and sister provoked him and he was forced to retaliate. It was clear that as he described his active forms of revenge, a characteristic smile of pleasure came over his face.

He was angry at his mother, who was always hovering and worrying about him, and who thought he was terrible. He wished she would "just get off his back." With pleasure he described some of the boys of the Lepke gang; he felt much pride that he was a fully accepted member, though he was the youngest. $\mathrm{He}$ spoke of the huge collection of Playboy magazines the group accumulated.

Roger told his therapist, during the evaluation sessions, that he was not going to see him. He was boring and probably charged too much, and he could not make him stay. He ended these sessions, however, by relating a recent nightmare -a dream in which his mother's severed head was rolling in the living room. He was visibly anxious and agitated as he described the dream. The leap between defiance and opposition to anxiety and neediness could fluctuate from moment to moment, and was characteristic of Roger in the early months of our work.

Roger clearly had difficulties in deaing with the strength of his aggressive impulses (both preoedipal and oedipal), the discharge of which was, at times, highly pleasurable. Though Roger was symptomatically heading toward an antisocial mode of behavior, he was clearly not psychopathic. Rather, we often see with these children like Roger a highly developed level of object relations and guilt about the unacceptable aggressive impulses toward objects. However, to accept the object demands, to accept societal admonitions and rules, means for many of these children to submit and suffer intense humiliation. Therefore, Roger struggles against the projected tormentors in his life. He becomes the aggressor, he turns passive into active. He challenges his therapist (the authority) immediately, rather than comply and be reduced to a frightened little boy.

\section{Course of Treatment}

Roger was seen twice weekly for about one-and-one-half years, and the course of the psychotherapy will be described as it unfolded. During the early months of treatment, Roger highlighted his delinquent exploits in a highly pleasurable, excited, and heroic way. He thoroughly enjoyed the Lepke gang activities: They developed techniques as Peeping Toms, they had continuous rip-off plans stealing from supermarkets, drug stores, etc. They had a constant store of liquor, cigarettes, and pot, which they used in the group. They were involved in guarding the turf of the neighborhood, letting no alien young adolescents use the playground or ride bikes on the streets. They enjoyed attacking the rich. For example, throwing eggs at Cadillacs was great sport. Similar feats were described at school: Roger discussed his techniques with spitballs, his protection of vulnerable girls against 
the older kids, etc. His greatest contempt was for the frightened and weak boys. He noted, with contempt, the "punks" and the "fags" that populated his schools.

Very occasionally, there would be a session in marked contrast to the unfolding of these daily exploits. He would then be extremely agitated and markedly upset. For example, he was beset by thoughts that his father would have a car accident, or die slowly of a heart ailment. He hated these thoughts and wanted therapy to get rid of them right now. He felt they would drive him crazy. He wanted to get away, to change schools, or move to another area where peace and tranquility could reign. The few occasions that guilt and anxiety reached consciousness were intolerable feeling states for him. The therapeutic task was to link this isolated misery with his more typical aggressive pleasure.

The therapist began to find occasions to make important connections. For example, the Lepke group, along with Roger, had been harassing an older couple in the neighborhood, a couple that Roger really liked. He subsequently became upset. He was responsive to the therapist's observation that he felt bad attacking these people, but a very important feeling drove him to join the harassment. No matter what, Roger could not stand being accused of being a chicken. He would always act to wipe out any hint of babyish "punk-fag" feelings in him. This theme of wiping out any potential "punk-fag" feeling, no matter what the cost, became a very familiar refrain.

He often reacted to his mother's concerns about getting into trouble by yelling at her and breaking something. Again he could slowly hear that he felt her message was that he was a helpless little boy. His furious response was to show that there were no "punk-fag" feelings in him. His father's rules, on some occasions appropriate, always made him feel like a "little shit" and he was forced to act. In fact, the therapist suggested again and again, that his daily exploits were to quiet the inside "punk-fag-chicken" worry. On one occasion in this period, Roger acknowledged that when he was little, he was afraid he would be drafted in the army and killed in a war, and also that his father was a member of the National Guard. He seemed to listen when the therapist responded that all little kids were frightened when they looked at the big giant father, the father who was a mustache man, and that does not really make them "punk-fags."

Similar themes permeated the transference. He could get mad with his therapist whenever he wanted to, he declared. He did not have to listen to a shrink or anyone who told the lies that his therapist told him. He walked out of the office on many occasions, or defiantly lit up a cigarette. Not only would he leave but also announced he would never return. The therapist became adept at spotting the need for the "tough Lepke gang" stance during the treatment hour. Could he be angry with the therapy now after he told the therapist about his old army worry? For him to have any kind of natural fear brought a big feeling of being ashamed. Or how worried he was about what was going on in treatment. If there was any change, if his "bad temper" became lessened in any way, he was very worried he would be left weak and helpless. Where would he be without his "bad temper?"

The work with Roger during the first year not only involved identifying his need to act to ward off helpless affects, but he also had many difficulties just containing stored-up rage. We saw an already familiar pattern: an outbreak of rage, and later apparently unconnected self-loathing. For example, on one occasion, the whole family attended a piano recital for the older daughter, who was an accomplished musician. Later, in celebration at a restaurant, Roger made an incredible scene, defiantly yelling at a minor request by his father. He ended by screaming, "I hate families," and the L. family left the restaurant abruptly. When the thera- 
pist discussed the event with Roger (the therapist received the news of the week in review from the parents), Roger focused on his father's rotten behavior. However, his characteristic smile of pleasure emerged when the therapist attempted to reconstruct the afternoon: how much he must have hated his sister, his wish that she would make a mistake during the concert and screw up, and how good it felt to finally ruin her day and get all his angry feelings out. The therapist predicted that he would later have a strong black sheep feeling. He responded immediately by talking of a dream he recently had about a dog who the family once owned. In the dream the dog "pissed and shit" all over the house, and was taken by the collar to the Humane Society by the father. It was clear Roger felt that he was the incorrigible dog who would be thrown out of the family and killed. The themes of his constant daily rage with those close-knit family members, his intense pleasure at upsetting them, and his strong feelings of being the outsider became very familiar ideas.

Roger began to speak more of his internal life. He talked about stories and books he read. The story of a white boy raised by Indians, or a child who lost his parents in World War II and survived in a concentration camp. When his feelings of being the abandoned orphan were discussed, Roger told his therapist of his conviction that he was really adopted and that he had often searched the house for his "papers." He came to identify these upsetting black sheep feelings, and also that his daily rage did make people treat him differently in the family. With this material, after a year of work, Roger's behavior began to change. He began working with his father, doing heavy "manly" construction work on the house, and redesigning furniture for his room. His father found him an energetic and amazing worker.

During the last six months of work, there were many behavior fluctuations in a good-bad Roger, with increasing periods of control. He had numerous problems on the school playground, and smilingly told his therapist he had a magnet in his pocket that attracted fights. The therapist noted that it was hard for him to tolerate the feelings (the identity) of being good. The therapist coined the phrase, "a fight during the day keeps the punk feelings away." A sudden disruptive episode with a teacher he was beginning to like was representative. Mrs. G was a teacher of German extraction, and one day he came to salute her with "Sieg Heil" in the classroom and answer all questions with "Ja wohl." It slowly became clear that he had become increasingly fond of her, was being used by her as a class monitor, and that he was overwhelmed with a "goody-two-shoes" feeling. His reaction was to disrupt the needy, caring, and tender identity.

Roger increasingly discused feelings that made him embarrassed. He had some current worries and not only fears of the past. He was still afraid of the army, and was relieved that there was no draft any longer. At times he had bad dreams. After seeing Jaws (the movie), he was beset by shark dreams. He recalled more childhood night fears of a white hand trying to choke him, or pirates who cut off limbs with a sword. Attempts to move into underlying sexual anxieties and masturbation were met with intense resistance. But Roger's daily self-observation increased. He reported potential "dares" that the former (before treatment) Roger would get involved in. For example, he often would break up some football play of older boys, intercept the pass, and run off. He knew it was just to prove that he was not scared, and that became a stupid idea because he would always get beaten up.

With Roger's good sustained functioning, there was pressure from him and parents to stop treatment. At termination, it was suggested that there might be 
flare-ups in the future, and that the therapist would be available for any crisis work.

\section{DISCUSSION}

The terms "character disorder" or "impulse character pathology" in children often evoke intense negative reactions within therapists. There is usually a dread of working with these children; they are considered untreatable, there is concern that they require a maximum of effort for a minimum of return, the families are considered uncooperative, and it is anticipated that the child's open aggression will mobilize anxiety, frustration, and counterrage.

Much of the generalized image of these children has come from the studies of the "antisocial" young child and adolescent of the 40's and 50's. The "children who hate" described by Redl and Wineman (1951) and the generation of delinquency and character pathology depicted by Irving Kaufman and Eveoleen Rexford $(1952,1959)$ have molded a conception of entrenched pathology. The instinctual urges within these unsocialized children remained unmodified. They were under the dominance of the pain-pleasure principle. There was atrophied conscience development, no emergence of guilt, and oral needs (especially greed related to stealing) were prominent.

It would be unfortunate to paint all "acting out" aggressive children with the same diagnostic brush. In our clinic, we saw significantly more children like Roger than like the more primitive destructive children described earlier. While there is a driven acting-out quality with many of our youngsters, much of it is often based on conflict. Wholesome object attachment and guilt is potentially available and, therefore, one can be much more optimistic about treatment potential. It is important to acknowledge that there are different kinds of impulse character pathology in children.

It is also helpful to differentiate our understanding of these children from other theories of "acting out" described in the literature. In our group, we saw little of the driven need for punishment that Ferenczi (1942) described as an important delinquent impetus in his patients. Similarly, Johnson and Szurek's (1952) dynamics of "superego lacunae" did not seem to fit our population. They described intense family interaction, particularly where the antisocial acting out is initiated, fostered, and unconsciously sanctioned by parental neurotic difficulties. While some vicarious pleasure in the exaggerated masculine traits was evident in the fathers of these youngsters in some of our sample, this did not strike us as a significant contribution to the pathology. Roger's mother and father 
MORTON CHETHIK

were effective and adequate parents with their other children. They were able to set appropriate limits generally, worked together on discipline, and evidenced no problems with excessive underlying rage. Their intense reactions, at times, was to an inflamed youngster who exhausted their patience. We were struck, in our sample, by the large number of parents who had developed relatively good parenting skills.

The concept of defense analysis, repeated repetitious interpretations, and working through of maladaptive behaviors has been a particularly helpful treatment strategy in our work. Some of Wilhelm Reich's (1963) early work on techniques in character analysis has been applicable. A major early goal with these children is to attempt to make the impulsive behavior internally ego alien. Often, as with Roger, the anxiety, unpleasure, and guilt are feelings split off from the acts and not seen as connected. It was enormously helpful to link clearly the dreadful consequences (e.g., with Roger, the unbearable dreams) with the daily problematic behavior (as punishments for his acts).

In a similar way, the behavior itself (e.g., the tough Lepke gang actions) immediately wards off frightening affects. As noted above, the process of turning passive into active wards off the weak, helpless images that induce intense shame and humiliation. Slowly verbalizing the self images the child fears (e.g., the punk-fag fears) and providing an acceptable developmental context for them is a critical part of the treatment process with these youngsters. We often also found that work with a prominent and generalized defensive process will be very repetitious, and that the multiple variations of the action mode used by the child needs to be interpreted.

There are some important countertransference tendencies and issues that typically emerge with these youngsters when they confront the therapist with sustained defiance and provocative behaviors. What are the internal reactions to blowing smoke in the therapist's face, writing "asshole" on all available newsprint, and elaborating the theme of uselessness of therapy? In our study group, two major counterreactions were stimulated within the therapy. One common reaction was rage, which could be handled by expressing it in some direct or subtle way within the treatment, or by suppressing the "unacceptable" feelings and not effectively limiting these youngsters.

Another major reaction was a subtle admiration for these youngsters, who on the surface appeared as though they were afraid of nothing. Our understanding the patient's internal dynamics were helpful in dealing with the countertransference trends. For instance, when Roger walked out of the treatment office telling the therapist he had better things to do, it became clear that he was trying to make the therapist small and helpless. Something was happening currently that incuded these unacceptable feelings within Roger, and he was attempting to re- 
CLINICAL SOCIAL WORK JOURNAL

verse the situation in his characteristic way. These mechanisms were common transference paradigms with these youngsters.

We have also found that with many of these youngsters, it has been difficult to explore fully many of the underlying issues. With Roger, for example, there remained unresolved aspects of positive oedipal drives (tender feelings toward women), homosexual longings, and masturbatory activities. It is not unusual that because of the developmental stages of these children, these unconscious conflicts may not be fully resolved. However, the rewards and pleasures for healthy functioning that come through the defense analysis often were extremely helpful and critical in altering the potential delinquent course.

\section{REFERENCES}

Eissler, K. (1948). Ego-psychological implications of the psychoanalytic treatment of delinquents. Psychoanalytic Study of the Child, 5, 97-121.

Ferenczi, S. (1942). Gulliver fantasies. International Journal of Psychoanalysis, 23.

Freud, A. (1946). The Ego and the Mechanisms of Defene. New York: International Universities Press.

Frued, S. (1937). Analysis Terminable and Interminable, Vol. 23, 2nd Ed. London: Hogarth Press.

Johnson, A.M., and Szurek, S.A. (1952). The genesis of the antisocial acting out in children and adults. The Psychoanalytic Quarterly, 21, 323-343.

Rexford, E.N. (1959). Antisocial young children and their families. L. Jessner and E. Pavenstead (Eds.), Dynamic Psychopathology in Childhood, pp. 186-220. New York: Grune \& Stratton.

Rexford, E.N. (1952). A developmental concept of the problems of acting out. Journal of American Academy of Child Psychiatry, 2, 6-21.

Redl, F., and Wineman, D. (1951). Children Who Hate. Glencoe, Illinois: Free Press.

Reich, W. (1963). Character Analysis. New York: Noonday Press.

Children's Psychiatric Hospital

University of Michigan Medical Center

Ann Arbor, MI 48109 